\title{
Continuing discontent among Soviet scientists over elections
}

\section{Moscow}

Continuing discontent with the Soviet Academy of Science's election of nominees to the Supreme Soviet took an extraordinary turn on 2 February - a public meeting of protest outside the academy's main building in Moscow which lasted for an hour and was attended by 3,000 people.

Although public meetings are becoming a routine part of the process of democratization, the meeting outside the academy was without precedent. It is only fair to say that the academy did nothing to prevent the meeting taking place. Indeed, the ground in front of the building had been cleared of snow on the eve of the meeting, which was entirely orderly. Afterwards, the president of the academy, Guri Marchuk, received a delegation of those present at the meeting.

The issue that has exercised the scientific public is the nomination on 18 January of candidates from the academy to the Congress of People's Deputies. As a result of the voting at that extended meeting of the academy's membership, the candidates who had received most support at meetings of institute personnel were found to be missing from the final lists. Rank-and-file scientists say the outcome shows their wishes have been neglected. The five resolutions passed at the meeting on 2 February show a deep crisis of confidence in the academic community.

The most remarkable occurrence then was the contribution of Academician Vladimir Kudryavtsev, elected a vicepresident of the academy only last year and put up at the meeting as the academy's spokesman. As chairman of the disputed election meeting, he could hardly have expected a hearty welcome from his critics, and there were several attempts to shout him down. He deserves praise for his determination to speak out.

"Read the slogans", he said at one point, "but I agree with most of them." "No to functionaries from science!' I also say 'No!' 'Scientists for Gorbachev and perestroika!' I also say 'Yes!' 'Let Sakharov, Sagdeev and Likhachev be our deputies!' I voted for them myself!"

Kudryavtsev went on to say that he agreed with the demand that the academy should be restructured and that a public association of scientific workers should be established. Saying that relations between the academy and its institutes should be more democratic, he asked for the meeting's help to this end.

On the outcome of the voting on 18 January, Kondryavtsev said he shared the meeting's "discontent and regret". Several days earlier, the praesidium of the academy had said that the results of the voting had come as a bolt from the blue for everybody. Academician Marchuk said that he had also voted for Sakharov and Sagdeev.

As an observer at the plenary meeting, had the impression that many leaders of the academy forgot to which body they were electing people, and by what principles and criteria. Counting the number of institutes backing one nominee or another

\section{IMAGE UNAVAILABLE FOR COPYRIGHT REASONS}

Post-glasnost Sakharov now free to travel - en route from Italy to Canada (AP).

should not have been irrelevant. Many failed to listen to Sakharov's appeal at the beginning of the meeting that there should be more confidence in the institutes' proposals. Although the voting was by secret ballot, the leadership must assume responsibility.

It is understood that the central electoral commission has said that there was "no violation of the law that would justify cancellation". But this view was not generally accepted by the commission, which agrees that the law should be further refined and made specific.

The affair is not yet over. One of the demands of the public meeting on 2 February was that the 23 candidates nominated on 18 January should now withdraw. There is also a proposal that the elections due in March should be boycotted to allow voting on a list drawn up by the institutes.

Sakharov, the front runner in the electoral process until 18 January, told me that he has now been nominated by several districts in the Moscow region and is not fully aware "who has appointed me, and where". Several other candidates disappointed at the academy elections, Academicians Dmitry Likhachev and Gavriil Popov, for example, have also been nominated by other constituents. But the fate of the academy's representation in the chamber of deputies will not be known until the special conference of the academy from 18 to 22 March. Yuri Kanin

Novosti

\section{Sagdeev declines to stand in Kazan}

Moscow

THERE has been a further escalation of the conflict within the Academy of Sciences over the nomination of candidates for the election of people's deputies. As Nature went to press this week, our Moscow correspondent Yuri Kanin learned that Academician Roald Sagdeev has declined to stand as a candidate for the city of Kazan, saying that he will instead "support with all my vigour" the staff of academy institutes in their "just fight against the scientific establishment".

Kanin writes: Sagdeev has been backed by staffers at 25 research institutes of the academy, but did not make it to the list of candidates put forward by the general meeting of the academy. Instead, he was nominated by the ethnic-territorial district number eleven of the Russian Federation, which consists chiefly of the city of Kazan.

In a cable to the electoral commission of the district, Sagdeev thanks the electorate for having nominated him, hopes that they will instead nominate local followers of Gorbachev's perestroika but declined to stand himself.

"I feel obliged", the cable says, "to support with all my vigour the staff of many institutions of the academy in their just fight against the members of the 'scientific establishment' sitting pretty at the academy's headquarters".

In an earlier interview, Academician Vladimir Kudryavtsev, the chairman of the general meeting of the academy at which the disputed nominations were made, explained that he had attended the public meeting in the academy's grounds on 2 February in a personal capacity. Saying that he had been surprised and disappointed by the outcome of the election, he denied the suggestion at the 2 February protest meeting that the list of those nominated had been drawn up by the praesidium of the academy.

Kudryavtsev also explained that while the praesidium has expressed regret at the outcome of the election, it could not have invalidated the result without flouting the procedure adopted at the outset of the election meeting. "Unless we learn to honour the laws, we will return to the times when we could only talk about democracy, while there was none".

Yuri Kanin Novosti 